Sirpa Aalto

Department of History, University of Oulu

\title{
The Connection between geographical space and collective memory in Jómsvíkinga saga
}

Geographical space and toponyms in saga literature have interested historians and archaeologists mainly as a way to connect the sagas to the physical world. Toponyms in sagas that depict past events have functioned for scholars as evidence that the sources are historical and have some kind of reliability ${ }^{1}$. The main objective of research has thus been to identify toponyms and place them on the map. In fact, most of the toponyms in the sagas can be identified without problems, but not all sagas provide accurate information about geographical conditions. For instance, legendary sagas are often set in distant and imagined places but usually connected to 'real' place names. In these cases, the imagined environment is part of the story that conveys the fantastic and does not intend to be credible but enhances the supernatural and fantastic in the saga (Marold 1996).

In addition to this very concrete function that the toponyms have in the sagas - namely, to give a setting for the story - I argue that the toponyms functioned also as a way to remember stories. Already the authors of Antiquity spoke of different techniques for memorization and these texts were known by medieval authors. For instance, Thomas of Aquinas wrote that a place could be used as a source for reminiscence. Francis Yates, who has written about mnemotechnical details that were used and developed by medieval authors as well as artists, speaks of different ways to remember things. She takes as an example medieval imagery used in manuscripts and art in general emphasizing the connection between vision and memory. Yates has developed this idea further when studying Thomas of Aquinas' four precepts for memory: according to her, Thomas' rules are based on the places and images of artificial memory and he loans - or actually develops - his ideas on basis of Classical authors. Thomas was concerned about memory techniques in general as a way to put things, i.e. memories in this case, in order. Yates takes this idea further and says that "we are at liberty to imagine places and images of the artificial memory as in some way the 'sensible' furniture of a mind"

\footnotetext{
${ }^{1}$ See for instance discussion in Rory McTurk, "Harđar saga. Bárđar saga. Porskfirđinga saga. Flóamanna saga. pórarins páttr nefjólfssonar. Porsteins páttr uxafóts. Egils páttr Síđu-Halssonar. Orms páttr Stórólfssonar. porsteins páttr tjaldstœðings. Porsteins páttr forvitna. Bergbúa páttr. Kumlbúa páttr. Störnu-Odda draumr. ed. by Pórhallu Vilmundarson and Bjarni Vilhjálmsson. Ílenzk fornrit XIII, Reykjavík 1991." (Review), Saga-book XXIV, (1994-97), $164-172$.
} 
(Yates 1966: 72). To bring this to the theme of my article, I propose that toponyms can function as memory places - as a 'furniture of mind' - in Old Norse-Icelandic sagas.

I investigate toponyms in one particular saga, Jómsvíkinga saga, in order to find out what kind of role they have in the process of memorization the story. If the toponyms function as memory places, we should be able to discern at least some toponyms that should be found in all the redactions of the saga. The article discusses how toponyms are related to the concept of collective memory and it contributes to the ongoing discussion of memory studies in saga literature. $^{2}$

Jómsvíkinga saga is well suited for this purpose because it is recorded in more than one manuscript, giving the possibility to compare the two main lines of the stemma (see Sources). Yet the number of manuscripts is limited, which makes the overall study of toponyms in different redactions manageable. The purpose of the comparison is to investigate whether there are toponyms that are shared by all redactions of Jómsvíkinga saga and what this means for the saga narrative and memorization. This also applies to the opposite direction. What can we deduce from those toponyms that appear only in one or a few redactions of the saga?

Jómsvíkinga saga and its background

Jómsvíkinga saga is thought to have been written down early in the 1200 s, but the core of the story may have appeared in a form of the drápa earlier or around the same time.

Jómsvíkingadrápa was composed by Bishop Bjarni Kolbeinsson (1188-1223), most probably at the end of the $12^{\text {th }}$ century (Fidjestøl 1993: 48; on the oral background of the saga, see Finlay 2006: 250; Emily Lethbridge 2012: 954). The saga is set in the latter half of the $10^{\text {th }}$ century in Denmark and Norway. At the core of the story is a Danish nobleman Pálna-Tóki who becomes the enemy of his former foster son, King Svein Forkbeard of Denmark (ruled c. 986-1014). Pálna-Tóki flees Denmark and goes on Viking raids with his crew. In Wendland (the West Slavic area on the southern coast of the Baltic Sea) he is offered an island, Jóm, by Prince Búrizláfr. Pálna-Tóki’s duty is to defend Búrizláfr's realm from other Vikings, so he builds a fortress on the island.

\footnotetext{
2 Joseph Harris, "Old Norse Memorial Discourse between Orality and Literacy" In Along the Oral-Written Continuum: Types fo Texts, Relations, and Their Implications. edited by Slavica Ranković, Leidulf Melve, and Else Mundal, 120-33. Turnhout: Brepols 2010; For instance a whole issue of the Scandinavian Studies was dedicated to methodological aspects of cultural memory in sagas. Scandinavian Studies 3:2013; Pernille Hermann \& Stephen A. Mitchell \& Agnes S. Arnórsdóttir, Minni and Muninn: Memory in Medieval Nordic Culture. Turnhout: Brepols 2014.
} 
The Vikings of the island of Jóm, Jómsvikings, become famous for their strict law code and their fierce fighting. After the death of Pálna-Tóki, the new leader, Sigvaldi, is eager to marry Prince Búrizláfr's daughter but Búrizláfr set one condition for the marriage: Sigvaldi must bring King Svein to Wendland. Prince Búrizláfr was tired of paying tribute to the Danes, and he wanted the king to cease to demand it. Sigvaldi, himself also of the Danish upper class, lures King Svein to his ship and kidnaps him and brings him to Prince Búrizláfr's court. King Svein has no choice but to accept the terms. The deal is confirmed with marriage alliances so that King Svein is to marry one of Búrizláfr's daughters and Búrizláfr himself will marry the sister of King Svein.

King Svein wants to avenge the treacherous act of Sigvaldi, so he invites the Jómsvikings to a feast where they will drink in honour of Sigvaldi's deceased father. At this feast the Jómsvikings become heavily intoxicated and King Svein persuades them to promise that they will attack his enemy, Earl Hákon of Norway. After the feast the Jómsvikings realize that their promise has to be fulfilled or they will lose their honour. They set out on the expedition with the Danish fleet immediately after the feast, before the Earl could hear about their boasting.

The saga climaxes with the battle of Hjörungavágr somewhere on the west coast of Norway. According to the saga, Earl Hákon has to rely on his protective goddess Porgerðr Hörðabrúðr in order to win the battle: the goddess and her sister Irpa raise a hail storm which changes the tide of the battle. Sigvaldi flees with part of the fleet, while some of the Jómsvikings are captured. The end of the saga concentrates on depicting the beheading of the prisoners and how the rest of them survive because of their brave attitude.

All in all, Jómsvíkinga saga is an entertaining saga with a clear connection to historical events (Morawiec 2009: 139; Bagge 2010: 26 - 27). The entertaining side of the saga has affected the later reception of the saga. When the saga was supposedly written down, around year 1200 , saga writing had just begun in the form of hagiographies and kings' sagas, which could also explain why the saga is difficult to place in any one saga genre (Berman 1985; Aalto 2014). Apparently the saga was supposed to combine a good story and past events. Even if Jómsvíkinga saga may have been intended to be a historical work, it later became entertainment (Aalto 2014).

The saga concentrates in the beginning on events in Denmark, because the plot of the saga is intimately connected to the Danish royal house. Although the base of the Jómsvikings is 
situated in Wendland, it does not play a prominent role as a place for action. In the end of the saga, Norway is in the focus of action, which is clearly manifested in the toponyms.

\section{Sources}

Jómsvíkinga saga's stemma has been constructed most recently in 2000 (Megaard 2000). The saga survives in A- and B-redactions. It is unclear whether there was one common original version. A-redactions include the saga compilations Fagrskinna and Heimskringla, which are customarily dated to c. 1220 and c. 1235 respectively. B-redactions are manuscripts AM 291 4to (latter half of the $13^{\text {th }}$ century), Stockholm Pergament No. 74 to (beginning of the $14^{\text {th }}$ century) and AM 510 4to (mid- $16^{\text {th }}$ century). Jómsvíkinga saga is also incorporated to Óláfs saga Tryggvasonar in Flateyjarbók, which is dated to 1387. Jómsvíkingadrápa is used as a source as well, but it does not have much significance, because it contains only three toponyms. In this article I will use the above mentioned sources in order to answer following questions:

- Is it possible to find toponyms that appear in all the redactions?

- If so, what kind of functions do they have in the saga?

- Is it possible to connect their functions to the concept of collective memory or memorization?

- If there are toponyms that can be found in only one redaction, what kind of role do these have in the saga narrative?

Jóm/Jómsborg - the pivotal topym in the saga

Because Jómsvíkinga saga concentrates on events in Denmark and Norway, toponyms related to these realms have been taken as a point of departure in this investigation. The different redactions of the saga mention some toponyms outside of this sphere such as Bretland (Britain), Saxland (Germany) or Eystrasalti (the Baltic), but the purpose of the present investigation is to look at those Norwegian and Danish toponyms that are essential for the saga plot and compare them. However, one exception is made: the toponym Jóm/Jómsborg, which is pivotal in the saga, is taken into account and will be analysed first. As they are the most central toponyms in Jómsvíkinga saga, efforts have been made to establish the geographical locations of these two places (Finlay 2006: 252).

The island of Jóm, which gives its name to the Jómsvikings, is mentioned by all redactions of Jómsvíkinga saga except for Heimskringla. This may be due to the fact that Jómsvíkinga saga 
is embedded in Óláfs saga Tryggvasonar in Heimskringla, which means that the author Snorri Sturluson has not devoted much attention to Jómsvíkinga saga in general. Jómsvíkinga saga is, of course, embedded in another compilation as well, namely in Óláfs saga Tryggvasonar in Flateyjarbók, but in a much more extensive form than in Heimskringla. However, the absence of the toponym Jóm in Heimskringla is not a decisive difference, considering that Heimskringla does mention Jómsborg. Heimskringla states that when Svein (Forkbeard) was taken as king, Sigvaldi was earl over Jómsborg in Vinðland (Hkr I: 272). This gives the impression that the audience was expected to know Jómsvíkinga saga from elsewhere because the Jómsvikings and their background are not introduced in the saga (see the concept of immanent saga by Clover 1985: 293). Jómsborg, on the other hand, is mentioned in all other saga redactions, but is lacking from Jómsvíkingadrápa, which, however, mentions the toponym Jóm. It could be argued that Jóm is chosen in the poem instead of Jómsborg for artistic and metrical reasons. ${ }^{3}$

The location of Jóm/Jómsborg in the sources is very approximate. It is mentioned that it was located in Vinðland (Wendland), or that it was given as a fief to Pálna-Tóki by the Wendish Prince Búrisláfr. Wendland seems to lie somewhere on the outskirts of the 'known' world that is, it is an extension of the Scandinavian world (Aalto 2010: 115, 208). Some redactions of Jómsvíkinga saga describe how the fortress of Jómsborg appeared but these depictions hardly have any connection to reality. They tend to exaggerate the size of the fortress (for instance claiming that the harbor was protected by a stone arch and iron doors. AM 291: 63).

All in all, Jóm and Jómsborg do not play a role in the saga after the Jómsvikings are established as a group. Nothing special takes place there, yet it is still surprising how little attention is given to Jóm and its surroundings. One reason could be that the location of the island/fortress was forgotten by the time the saga was written down. As Alexandra Petrulevich has argued, the saga authors at the beginning of the $13^{\text {th }}$ century and thereafter only knew the name Jóm/Jómsborg from the story (which must have thus been oral tradition), but they could not connect it to places that they knew (Petrulevich 2009). No other Viking group is known by a name that connects a toponym to their name, so the Jómsvikings are a case of their own in saga literature.

\footnotetext{
${ }^{3}$ Petrulevich gives similar examples of toponym variants that can be epexegetic additions, e.g. Jómi: Jómsborg in the case of Jómsvíkinga saga, or Kotskógaborg : Kotskógur in Knýtlinga saga. Petrulevich 2013; On the etymology of Jómsborg, see Alexandra Petrulevich, Ortnamnsanpassning som process. en undersökning av vendiska ortnamn och ortnamnsvarianter i Knýtlinga saga. Uppsala: Uppsala universitet 2016, 170-173.
} 
The island of Wolin in Poland has been the primary candidate for Jóm. Archaeological excavations have proven that there was a lively trading place on the island and that there seems to have been a building that was inhabited by warriors (Petrulevich 2009; Stanisławski 2003). The trading place on the island was abandoned around the 1040s according to archaeological excavations. This fits well with the information from written sources which tell that King Magnús (the Good) made an expedition to Jómsborg around that time. Considering this background, it seems that Jóm/Jómsborg is an excellent example of how toponyms could continue to live on in (oral) tradition, although they do not testify per se that Jómsvíkinga saga as such is a reliable historical record. But the saga does not rely only on this toponym: depending on the redaction, there are other toponyms that are even more interesting from the point of view of their role in the collective memory connected to the Jómsvikings. The next sections deal with the toponyms in Denmark and Norway.

Toponyms concerning the Danish realm ${ }^{4}$

The toponyms Jóm/Jómsborg are thus in key position in Jómsvíkinga saga and they can be found in one form or another in all the saga redactions, but when it comes to other toponyms there is more variation among the different redactions of the saga. We begin by examining the toponyms connected to Denmark.

The Danish kingdom at the end of the $10^{\text {th }}$ century consisted of several parts, but Sjælland may have played the key role at that time. There was no capital in the realm, but there were several central places such as Viborg in Jutland and Lejre in Sjælland. The importance of these central places has been questioned - there may have been other, equally important places in the Danish kingdom in the Viking Age, but they have not emerged in archaeological excavations (Lihammer 2007). When looking at the Danish toponyms in Jómsvíkinga saga, it is clear that Sjælland (Hkr I: 272; Fsk: 122; AM 291: 52; Stock. P. no 7: 11; AM 510: 13; Flb.I: 160) and Bornholm are the most relevant for the saga. Bornholm, with its solitary location, may not have been central for the Danish kings, but according to Jómsvíkinga saga, two famous Jómsvikings, Búi digri and his brother Sigurðr, came from Bornholm (Hkr I: 272.; Fsk: 167; AM 291: 65; Stock. P. no 7: 15; AM 510: 30; Flb. I: 167). ${ }^{5}$ Other central places in the Danish realm are mentioned too, such as Funen, which is mentioned in all other

\footnotetext{
${ }^{4}$ The Danish kingdom at the end of the 9th century included areas that belong to present day Sweden (such as Scania and Halland) and Germany (Holtsetaland, i.e. Schleswig-Holstein).

${ }^{5}$ It is still debated when Bornholm actually became part of the Danish kingdom. Depending on one's viewpoint, this could have taken place between the $10^{\text {th }}$ and $12^{\text {th }}$ centuries. Lihammer 2007, 240.
} 
redactions of Jómsvíkinga saga except for Heimskringla (Fsk: 123; AM 291: 36; Stock. P. No 7: 72; AM 510: 3; Flb. I: 153). It is often forgotten that the southern part of present-day Sweden was part of the Danish realm until the mid-17 ${ }^{\text {th }}$ century. Scania, for instance, is mentioned in Heimskringla, Fagrskinna and Flateyjarbók (Hkr I: 272; Fsk: 124; Flb. I: 98). Halland is mentioned in three redactions of Jómsvikinga saga (AM 291: 50; Stock. P. No. 7: 11; Flb. I: 98).

The Danish mainland is not at the center of action, but Jutland is mentioned sporadically, as well as Hörð and Viborg which were located there (Fsk: 124). Flateyjarbók explains that Harða-Knútr got his name from Hörð, which was located in Jutland and where he was born. AM 510 is the only redaction that mentions Viborg (Vébjörg; AM 510: 21). It tells that Svein Forkbeard was accepted as king of the Danes at the assembly in Viborg. This information is in line with historical facts because it appears that the Danish kings had to be accepted in three assemblies: first in Viborg, then in Sjælland (Ringsted?) and in Scania. The other redactions mention that Svein travelled to Íseyrarping to get confirmation of his kingship, or that he travelled around Denmark to get his kingship confirmed (Hkr I: 272; AM 291: 72; Stock. P. no 7: 65; AM 510: 36-37; Flb. I: 170). ${ }^{6}$

Another place name that seems to have a central place in the Jómsvíkinga saga lore is Limfjord in northern Jutland. It is mentioned by all sources except for Fagrskinna and AM 510. It is from here the Jómsvikings set out for their expedition to Norway ( $\mathrm{Hkr}$ I: 277) and which Earl Harald had to cross when travelling to meet his daughter Queen Thyra and her husband King Gorm (Flb I: 102; AM 291: 7; Stock. P. no 7: 4). In AM 291 it is mentioned that Earl Harald of Holtsetaland (Holstein) travelled to meet his daughter Queen Thyra and her husband King Gorm and that he had to pass Limfjord. This would mean that the king and the queen were residing north of Limfjord, which is not the most obvious place for a royal residence. The ring fortress of Aggersborg is situated just on the northern side of Limfjord, and it is customarily dated to the latter half of the 10th century (to c. $980 \mathrm{AD}$ ), but its dating suggests that it cannot have been there during King Gorm's time. Moreover, it is questionable whether it would have functioned as a winter residence for the king as its function is usually connected to Svein Forkbeard's plundering expeditions to England. Another element in the saga that is not logical is that Earl Harald travels on horseback through Jutland to Limfjord, while one would guess that it would have been easier to sail to Limfjord from south to north.

\footnotetext{
${ }^{6}$ Íseyrarping appears in different forms, such as Seyrarping and Íseyri.
} 
This episode involving Earl Harald and his travel to Limfjord can also be found in Stock. Perg. no. 7 4to and in Flateyjarbók. (Stock. P. No 7: 56; Flb. I: 102). All in all, Limfjordalthough it must have been famous for Norwegians and Icelanders - seems to have another function in the saga than to demonstrate the historical reliability of events. This liminal aspect of Limfjord will be dealt further in this article.

Apart from these aforementioned toponyms in Denmark, there are some differences between the redactions. They all mention toponyms in the Danish realm, but there is often no equivalent passage in other redactions. In Heimskringla, Fagrskinna and Flateyjarbók these toponyms are sporadic (Hkr I: 272 (Ísafjorð); Fsk: 124 (Hringstoðum); Flb. I: 98 (Hörð)), but in AM 291 and AM 510 there is more than one Danish toponym that cannot be found in other redactions. In AM 291, the place where King Harald and the Emperor fought is specified with the toponyms Slesdýr and AEgisdýr, which were located in the southern part of Jutland, present day Schleswig. It describes how the rampart Danevirke was built between Agisdýr and Slesmynni (AM 291: 24-27). In AM 510 we can read that Svein (Forkbeard) receives ships from his foster father Pálna-Tóki and father King Harald Bluetooth. He sets out on a plundering expedition to Denmark, and in this context the toponyms Eyiar-lond, Langa-land, Saland and Maun, all of them Danish islands, are mentioned (AM 510: 13).

Fagrskinna mentions two Danish toponyms that are lacking in other versions. First of all, it mentions that King Svein invited the Jómsvikings to his feast in Ringsted on Sjælland, which sounds plausible, considering the central position that the island had in the Danish realm. Secondly, the saga mentions that Pyra, sister of King Svein, held possessions on Danish islands, among others on Falster (Fsk: 123-124). Later, when Pyra flees from Prince Búrisláfr whom she does not wish to marry, and instead marries King Óláfr Tryggvason, her dowry (which presumably consists of land possessions) is negotiated by King Óláfr and his former father-in-law Prince Búrisláfr.

These toponyms show fairly accurate knowledge of Danish geography. Agisdýr, Slesmynni and Slesdýr are mentioned only in AM 291 and the islands Langa-land and Maun only in AM 510. This could indicate that those who copied or modified the saga added their own information, or that they had in hand, or had heard versions containing these details. This can never be proven and remains an educated guess. We also have defective details about Danish geography, for instance the suspected location of Limfjord. AM 510 does not mention it at all, because the manuscript lacks the "introduction" - i.e. the early history of the Danish royal 
house before Harald Bluetooth - included in other redactions. Nor does it mention Limfjord as a place from which the Jómsvikings would have set out on their expedition to Norway. Generally the differences between the Danish toponyms found in different redactions of Jómsvíkinga saga are not great. For instance, AM 291 mentions four toponyms that cannot be found in other versions, while AM 510 mentions three, Fagrskinna two and Flateyjarbók one.

All in all, we can say that although the Danish toponyms in different redactions of Jómsvíkinga saga are generally not very precise and tend to mention just a few bigger places such as islands, there are also small differences among the redactions. Of all the Danish toponyms only two are mentioned in all redactions, namely Sjælland and Bornholm. As the examples of AM 291 and AM 510 show, for some reason the authors of these manuscripts added geographical details that are lacking in other redactions. Were they more aware of the geographical context of the saga in general? How important was it for the story to present Danish toponyms? I argue that the Danish toponyms were not as important as Norwegian ones, because the saga climaxes in Norway. A comparison between the Norwegian and Danish toponyms used in the saga may therefore cast light on the matter.

\section{Toponyms in Norway}

It is interesting to see what kind of pattern the redactions of Jómsvíkinga saga display in relation to Norwegian toponyms. Are AM 291 and AM 510 more precise than other manuscripts with toponyms in Norway like they are with Danish toponyms? Again, quantitatively the differences are not great. AM 291 mentions two toponyms (Liðandisnes, Solundir) that are not attested in other Jómsvíkinga saga-redactions, while AM 510 mentions two toponyms unique to that version (Eyrjar, Mannhaugr). The compendia that contain Jómsvíkinga saga have also deviant toponyms: Heimskringla has three (Hkr I: 275-277, 286 : Raumaríki, Uppland, Ogðum), Fagrskinna has one (Fsk: 128: Elptrum), and Flateyjarbók has three (Flb. I: 185, 187: Hjörungar, Fialafylke, and Fliodum). We can, of course, ask, whether a form such as Hjörungar in Flateyjarbók is very different from Hjörungavágr and Hjörungafjorðr. Contextually, it refers to the same place as Hjörungavágr and Hjörungafjorðr, and Flateyjarbók also gives the more familiar name Hjörungavágr. In addition, four redactions of Jómsvíkinga saga give another variant: Hörund (AM 291: 108; Stock. P. No 7: 72; AM 510: 70; Flb. I: 187). ${ }^{7}$

\footnotetext{
${ }^{7}$ Again, this kind of variation in toponyms reveals that the tradition may have existed in several forms, others being just epexegetic additions. Petrulevich 2013.
} 
When we look at all the Norwegian toponyms mentioned in different redactions of Jómsvíkinga saga, six toponyms are common to all versions: Gimsar, Hereyjar, Hjörungavágr, Naumudalr, Stað(ir), and Viken. If we analyse these one by one we can note the following: Hereyjar is mentioned when the route to Hjörungavágr is described (Hkr I: 279; Fsk: 127; AM 291: 106-107; Stock. P. no 7: 71-72; AM 510: 67-68; Flb. I: 186). Staðir is mentioned when the Jómsvikings and the Danes arrive in Norway, and when their army was north of Staðir and stayed in Hereyjar (Hkr I: 278; Fsk: 127, 131; AM 291: 105-106; Stock. P. no 7: 71; AM 510: 66, 71; Flb. I: 186).

Hjörungavágr itself is central to the story, which means that it would be impossible to conceive of the saga without it. Gimsar is mentioned when the saga tells about the origin of Earl Hákon's man Styrkárr af Gimsum (Hkr I: 278; Fsk: 131; AM 291: 109; Stock. P. no 7: 72; AM 510: 71; Flb. I: 188). Naumudalr is mentioned when Earl Hákon sends his son Eiríkr to collect men from different parts of Norway to fight the Danes (Hkr I: 276; Fsk: 131; AM 291: 104; Stock. P. no 7: 71; AM 510: 65; Flb. I: 185). Viken is important because the main antagonist of Vagn Ákason is Porkell leira from Viken (Hkr I: 279; Fsk: 127, 131; AM 291: 34; Stock. P. no 7: 71, 77; AM 510: 60; Flb. I: 181).

Analyzing the toponyms

These aforementioned toponyms in general can be divided into following categories: 1) toponyms in Danish and Norwegian realms that give general background for the saga; 2) toponyms that describe the route (from Denmark) to Hjörungavágr that the Jómsvikings and Danes took; 3) toponyms that indicate where saga characters came from; 4) single toponyms (Limfjord, Primsignd) that have other functions.

As has been pointed out, the common toponyms for the saga redactions are not many, two concerning the Danish realm and six concerning the Norwegian. When looking at the context of these toponyms, following remarks can be made: Danish toponyms Sjælland and Bornholm function as background information for the saga plot. Some of the events take place on Sjælland, and Bornholm was, as mentioned, the home island of Búi digri and Sigurðr. Roughly half of the toponyms concern the route from Limfjord to Hjörungavágr. Although only two of them - Hereyjar and Staðir - are mentioned by all redactions, the redactions do mention other toponyms on the route but there is slight variation which toponyms appear in them. My conclusion based on this evidence is that we can claim that the common toponyms 
form an integral part of the Jómsvíkinga saga lore that climaxes in the battle of Hjörungavágr.

The depiction of the route to Hjörungavágr could be compared with the poem Tøgdrápa by Pórarinn loftunga. The poem tells about the voyage that King Knútr inn ríki (Cnut the Great) undertook between 1028 and 1030 as he assumed control over Norway. It has an itinerary-like structure and it enlists toponyms on Norwegian coast as the voyage proceeds from south to north. ${ }^{8}$ The poem has only two common toponyms with the redactions of Jómsvíkinga saga. The two common toponyms are: Limafirði (Limfjord, st. 1) which is located in Denmark but which is the starting point for King Knútr's voyage as well as for the Jómsvikings, except in Fagrskinna and AM 510, and Stað (Stad, st. 4), which is found in all redactions of Jómsvíkinga saga. ${ }^{9}$ This comparison would support the claim that at least Staðir playes an important role in the saga as it is one of the key locations where the Jómsvikings and Danes stop before the decisive battle.

Category 3, which consists of toponyms connected to personal names, are typical of saga literature. The geographical origin of a character is one way of differentiating him from other characters with the same name. In addition, where a character comes from would inevitably reveal something about his loyalties. The Jómsvíkinga saga redactions (except for Heimskringla) even specify where those Icelanders, who participated in the battle, came from (Fsk: 131; AM 291: 111; Stock 7: 72; AM 510: 73, 101; Flb: 188, 203).

Category 4 covers two single toponyms that are difficult to put in the above mentioned categories, or they have an aspect that makes them special. These toponyms are Limfjord and Primsignd. Limfjord is, obviously, important in many ways because it is often connected to turning points in the saga: It is the place where Earl Harald tries cross the fjord to meet his daughter and son-in-law, Earl Hákon of Norway and Gull-Harald fight, and the Jómsvikings set out on their journey to Norway. It is also a place which seems to have a function as a gate to liminal space in Jómsvíkinga saga. It is a passage between this world and the other world. For example, when Earl Harald of Holtsetaland is trying to travel to meet his daughter Queen Pyra and travel across Limfjord, he is hindered by several supernatural omens.

\footnotetext{
${ }^{8}$ Matthew Townend, "Tøgdrápa” In Diana Whaley (ed.), Poetry from the Kings' Sagas 1: part 2. Turnhout: Brepols, 851-863.

${ }^{9}$ There is one other common toponym, Egđir (people of Agder, st. 2), which is found in Heimskringla (Hkr I: 277).
} 
Another liminal space in Jómsvíkinga saga could be the island of Primsignd. The name refers to Latin term prima signatio, which was used for those who were willing to accept teaching in Christianity but were not yet baptized. Dramatically, this island is the place where Earl Hákon takes his youngest son and offers him to his protecting goddess Porgerðr Hörðabrúðr. Primsignd, which appears only in Stock. perg no. 7, AM 510 and in Flateyjarbók, is probably invented to give a dramatic background for the horrible sacrificial scene: pagan sacrifice is made on an island that is connected to conversion. This gives emphasis on Earl Hákon's character as an archetype of a pagan leader.

Differences between A- and B-redactions

As has been pointed out in earlier research, the manuscripts of Jómsvíkinga saga can be divided into two main groups, so-called A- and B-redactions (Megaard 2000). It is relevant to compare these with one another in order to see whether they share toponyms. Indeed, there are some similarities. For instance, the A-redactions Heimskringla and Fagrskinna mention the following toponyms that are lacking in B-redactions of the stemma: Arvík (Hkr I: 279; Fsk: 131), Yrjar (Hkr I: 279; Fsk: 131), and Valdres (Hkr I: 285; Fsk: 131). As the references show, all these toponyms occur in the same passage, which mentions men on Earl Hákon's side and where they came from.

The B-redactions (manuscripts AM 291 4to, Stock. P. No 7 4to, AM 510 4to, Flb.) have the following shared toponyms: Hörund (AM 291: 108; Stock. P. no 7: 72; AM 510: 70; Flb. I: 187), Sunnmфre (AM 291: 105; Stock. P. no 7: 71; AM 510: 64-65; Flb. I: 186), Túnsberg (AM 291: 100; Stock. P. no 7: 71; AM 510: 60; Flb. I: 183) and Dalir (AM 291: 109; Stock. P. no 7: 72; AM 510: 88-90; Flb. I: 188). These toponyms are also connected to the final events in Norway. The Jómsvíkings arrive first in Túnsberg (Tønsberg) and continue to Sunnmøre. Hörund is described in relation to Hjörungafjöror and Hjörungavágr, where the battle takes place. Dalir is the place where one of Earl Hákon's supporters, Guðbranðr, comes from.

This division of common toponyms in the B-redactions shows similarities to common toponyms in the A-redactions: they all relate either to the Norwegian geography that is described when the Jómsvíkings are looking for Earl Hákon in Norway, or they are toponyms related to introducing characters. This, again, would suggest that they had meaning for the tradition of the saga. It would point to two slightly different traditions of Jómsvíkinga saga and support the division into A- and B-manuscripts. 
It could be concluded that especially the toponyms common to all saga versions must constitute some kind of reminiscence of the core of the Jómsvíking tradition. This study does not aim to confirm the relationships between the different saga manuscripts, i.e. the stemma. Nonetheless, it should not be disregarded that there exists a set of toponyms that is shared on the one hand by all the redactions and on the other hand, there are toponyms and can be found only in A- or B-redactions. A similar investigation between A- and B-redactions could be made of personal names.

\section{Discussion: Toponyms as aide-mémoires}

My hypothesis is that the toponyms in Jómsvíkinga saga constitute an aid for remembering the story, based on ideas of Francis Yates, who has introduced the concept of places as 'sensible furniture of mind'. Anchoring the story to certain places helps the author to remember the rest of the story (Carruthers 2008: 158). It could be asked whether it could work the other way round, too: toponyms help recall stories in the landscape. This is certainly true when it comes to the connection of landscape and memory around one's immediate surrounding, but how about places that we have never been to? The author/copyists of Jómsvíkinga saga probably did not visit Hjörungavágr, but they were able to recite the route there. I would claim that Carruthers statement is valid when we consider places that are not in our vicinity which excludes the possibility that one could recall a story by looking landscape. For instance, the toponyms in Jómsvíkinga saga would be distant for Icelanders. Retelling the saga would require that certain pivotal toponyms, at least Jóm/Jómsborg and Hjörungavágr, would be part of the story, and that would require memorization of the core of the saga.

The toponyms in Jómsvíkinga saga are concerned with presenting places of action and the backgrounds of characters. In spite of differences among different redactions, it can be said that the Norwegian toponyms are more specific than the Danish ones. It has been assumed that this is due to the Icelanders that brought the story to Iceland and continued to cherish it (Hollander 2008, 20). ${ }^{10}$ This is a plausible explanation, but it is worth considering the mnemonic value of toponyms: it is very crucial for the plot of the saga to depict the direction from which the Jómsvikings approached Earl Hákon and where the final battle took place. This is not to say that the authors/copyists (or the audience) themselves could necessarily locate the toponyms accurately. For instance, Jóms/Jómsborg was most probably a very

\footnotetext{
${ }^{10}$ Jómsvíkinga saga has connection to Icelanders, because some Icelanders participated in the Battle of Hjörungavágr.
} 
distant, almost abstract, place to them. However, Jómsvíkinga saga was remembered exactly with help of the essential toponyms Jóms/Jómsborg and Hjörungavágr, and based on my previous suggestion, also some other common toponyms found in the redactions. It would have been important for the saga plot to remember that the Jómsvikings made a stop at Staðir, or that the men who participated in the battle on Earl Hákon's side were Guðbrandr from Dalir and Porkell leira from Viken.

While I argue that Jómsvíkinga saga uses common toponyms as a way to aid remembering, I cannot confirm without further research that this is the case with other sagas too, although I consider it to be most probable. How to explain then the differences among the redactions? Memory is sometimes compared to a leaky bucket, reflecting how memory diminishes and things can drop out of memory over time (Hermann 2014: 25). This metaphor would explain how some toponyms could drop out of a saga, especially if they are not vital for the plot. This works the other way round too: the author/copyist could also add new information that did not belong to oral tradition. Alexandra Petrulevich has pointed out that sometimes the toponyms in the sagas can be later inventions and they do not necessarily reflect oral tradition (Petrulevich 2013).

As an example of the complex connection between oral tradition and place names we may take Landnámabók in which there are instances where 'ancestors' and their deeds have been extrapolated from place names, demonstrating oral tradition can be misleading or even intentionally falsified. Falsified or not, oral stories and folk legends make use of place names. They give historical depth to their surroundings. As the example of Landnámabók shows, local history is rooted in place and landscape. In many cases, place name etymologies refer to the first inhabitants of the region or the early events there (Gunnell 2008: 15, 57-58; cf. discussion in McTurk 1994-1997). Landnámabók may not be the best comparison to Jómsvíkinga saga as the background and context of the sagas are different: Landnámabók was written by Icelanders who were concerned about their own past in their own country whereas Jómsvíkinga saga represents a different saga genre. Yet it, too, was part of the building of Icelandic identity and past.

Memory studies

It seems likely that early Scandinavians would have shared with many other oral societies the process of memorization by generative reconstruction of a work's component elements rather by rote learning (Goody 1987: 167-190). This question is connected to the concept of 
collective memory. The concept of collective memory was introduced by Maurice Halbwachs who published the book La mémoire collective in 1950. Collective memory is understood to refer to memories and information that individuals in a given group share with each other. Halbwachs suggested that each generation creates its own identity by comparing it to the constructed past. Collectivity holds community together with the help of the shared past and ceremonies that confirm the collective identity of the group members. This means that collective historical memory encompasses both continuity and new ways of interpreting the past (Coser 1992: 24-27).

If collective memory is essentially a social construction, what was considered to be worth remembering and by whom? This question cannot be answered comprehensively in this article and it is by no means my purpose, but it is certainly worth considering the meaning of Jómsvíkinga saga for the Norse-Icelandic tradition and culture. Indeed, the sagas have been compared to memory, since they comprise knowledge and narratives (Hermann 2013: 350; Hermann et al. 2014: ix-x). Jómsvíkinga saga seems to have been viewed as worth remembering, inasmuch as it was included in two saga compilations and also survives as a separate, "independent" saga in several manuscripts. It could be part of the Icelandic interest in history and identity building through history, or simply indicative of their love for adventurous stories as an expression of escapism (Aalto 2014; Clunies Ross 2009). Based on this, it would seem that Jómsvíkinga saga would be part of collective memory. The different versions of the saga show that it was never "canonized", which means that they could go on living (Assmann 2006, 39). ${ }^{11}$

The common toponyms in Jómsvíkinga saga redactions reflect collective memory because 1) they functioned as memory places that connected the story to physical place (which, of course, could be either real or imaginary), and 2) they are an important part of the plot in the sagas. To apply Yates' expression 'furniture of mind', certain pieces of furniture are indispensable for the memory. Toponyms as pieces of 'furniture of mind' help the audience to locate the story either on a concrete or on an abstract level. Pernille Hermann has compared the spatial dimension in Old Norse-Icelandic literature with 'mnemonic places' or 'mnemonic images' that most likely had an organizational function for the literature (Hermann 2014: 29). Jóm/Jómsborg and Hjörungavágr are without doubt 'mnemonic places' in Old NorseIcelandic literature. For instance, Knýtlinga saga, which describes very briefly how

\footnotetext{
${ }^{11}$ Assmann has pointed out that canonization of texts fundamentally changes their cultural continuity.
} 
Jómsvikings set out on the military expedition against Earl Hákon, mentions only Hjörungavágr and none of the other important toponyms in Jómsvíkinga saga redactions (Knýtlinga saga: 97).

Collective memory participates in construction of collective group identity, which is based on shared things such as ideas, values and memories (about past). Kirsten Hastrup has said that the landscape is the topos of identity (Hastrup 1998: 112), which connects fittingly how places and landscape are part of group - and also individual - identities. Hastrup's statement concerned perhaps mostly the Sagas of Icelanders, but certainly sagas in general participated in identity construction among Icelanders. Through sagas Icelanders built their group identity and important part of it was reflecting it with the outer world and groups living there (Jakobsson 2005). To widen Hastrup's idea, not just landscape in Iceland but also the world outside of Iceland was part of Icelanders' identity building. It could be asked how Jómsvíkinga saga contributed to the construction of the Icelandic identity - at least it was important for Icelanders to mention which Icelanders participated in the final battle and who brought the story to Iceland.

It is clear that there are certain toponyms in the saga literature that stand out from others and that are associated with certain events as part of the collective memory, as seen in Jómsvíkinga saga. Such toponyms could include Svold (Svolder, Svöld), which is an unknown place in the southern part of the Baltic Sea where King Óláfr Tryggvason was defeated, or Stiklastaðir, where King Óláfr Haraldsson lost his life (see also Morawiec 2009: 117). These toponyms, even with obscure geographical locations like Svold or Jóms/Jómsborg, have become important lieux de mémoire in Old Norse tradition (Nora 1989, 12). ${ }^{12}$ As Jürg Glauser has pointed out, sagas semioticize landscape - they map it and transform nature into landscape. In the end, semioticization of landscape forms a trope of memory (Glauser 2009: 209; see also Glauser on 'spatial modes of thought' in Glauser 2007: 19-20). I think that some of the lieux de mémoire in Old Norse tradition have become such tropes - it would be enough to hear the place name and it would evoke points of resemblance to particular sagas.

Admittedly, toponyms are far from being the only aids for memory. A narrative may employ various techniques to highlight a story, but as Margaret Clunies Ross has argued, this requires a mental model that assumes the existence of a unique pattern of events occurring over time.

\footnotetext{
12 Pierre Nora has used the term lieux de mémoire to describe concrete (museums, archives) and abstract (festivals, anniversaries) places that disseminate and reconstruct collective memory.
} 
Toponyms are essential for the narrative, whether it is assumed to be fictional or historical, because the audience has to be capable of interpreting the story. Therefore, the narrative has to have the property of being able to represent a comprehensible world for the audience (Clunies Ross 1994:24).

Concluding remarks

Certain toponyms in Jómsvíkinga saga are crucial for the saga, such as Jóm/Jómsborg, where the Jómsvikings are founded, and Hjörungavágr, where they are defeated. As I have shown above, these toponyms hold an important place in the different saga redactions and they are mentioned in all of them in one form or another. The analysis of Danish and Norwegian toponyms in Jómsvíkinga saga shows that there is a certain core of toponyms that can be found in all the different redactions. This core is not very big in number (only six common Norwegian and two Danish toponyms).

Based on the analysis of toponyms in Jómsvíkinga saga I suggest that the toponyms have different functions in the saga. On the one hand they form background for events and characters, which is obvious, but nevertheless important to point out as they define how engaged the redaction in question is to frame the plot. On the other hand, the toponyms common to all redactions show that they serve as memory aids for the narrative and they become part of the collective memory. I have applied in this article Francis Yates concept of toponyms as 'furniture of mind' meaning that the toponyms function as mnemonic places that help remember the saga plot. Certain 'furniture' in the plot are irreplaceable - in this case the common core toponyms. Without them the saga would not be the same.

Differences in toponyms, that is, toponyms that appear in one or only in few redactions, can be interpreted as assign of either different traditions (A- and B-redactions), or personal knowledge on the part of the author-copyist, who wanted to be more specific with toponyms and added them. As I have suggested, similar experiment could be made with personal names because toponyms are by no means the only mnemonic places in the sagas. This kind of investigation would show, which characters stand in the core of tradition, and whether A- and B-redactions differ in a similar way as they do with toponyms.

I want to thank the anonymous reviewers for their useful comments and Dr. Jakub Morawiec for fruitful discussions concerning the Jómsvikinga saga's connection to memory studies. 
Sources

AM 510 = Jómsvíkinga saga [AM 510]. Petersens, Carl af (ed.). 1879. Lund.

AM 291 = Jómsvíkinga saga efter arnamagnceanska handskriftfen N:o 291 4:to [AM 291]. Petersens, Carl af (ed.). 1882. Lund.

$F s k=$ Fagrskinna. Bjarni Einarsson gaf út. 1979. Reykjavík.

Flb. $I$ = Flateyjarbók $I$. En samling af norske konge-sagaer. 1860. Christiania.

Hkr I = Heimskringla I. Bjarni Aðalbjarnarson gaf út. 1985. Reykjavík.

Knytlinga saga. Danakonunga sögur. Bjarni Guðnason gaf út. Íslenzk fornrit XXXV. 1982. Reykjavík.

Stock. P. No 7 = Jómsvíkinga saga efter skinnboken 7, 4to å Kungl. Biblioteket utgifven af Gustaf Cederschiöld [Stock. P. No 7, 4to]. 1875. Lund.

\section{Literature}

Aalto, Sirpa 2010. Categorizing Otherness in the Kings' Sagas. Joensuu: University of Eastern Finland.

Aalto, Sirpa 2014. ”Jómsvíkinga saga as a part of Old Norse historiography", Scripta Islandica 65: pp. 33-58.

Assmann, Jan 2006. "Invisible Religion and Cultural Memory" In J. Assmann, Religion and Cultural Memory. transl. by R. Livingstone [Religion und kulturelle Gedächtnis, 2000], Stanford: Stanford University Press, pp. 31-45.

Assmann, Jan 2010. "Memory, Narration, Identity: Exodus as a Political Myth" In H. Liss \& M. Oeming (eds.), Literary Construction of Identity in the Ancient World: Proceedings of the Conference Literary Fiction and the Construction of Identity in Ancient Literatures: Options and Limits of Modern Literary Approaches in the Exegesis of Ancient Texts, Heidelberg, July 10-13, 2006. Winona Lake: Eisenbrauns, pp. 3-18.

Bagge, Sverre 2010. From Viking Stronghold to Christian Kingdom. Copenhagen: Museum Tusculanum Press.

Berman, Melissa 1985. “The Political Sagas”. Scandinavian Studies 57, pp. 113-129.

Carruthers, Mary 2008 [1990]. The Book of Memory. A Study of Memory in Medieval Culture. Cambridge: Cambridge University Press.

Clover, Carol 1985. "Icelandic Family Sagas" in C. Clover \& J. Lindow (eds.), Old NorseIcelandic Literature. A Critical Guide. Islandica XLV. Ithaca and London: Cornell University Press, pp. 239-315.

Clunies Ross, Margaret 1994. Prolonged Echoes. Old Norse Myths in Medieval Northern Society. 1: The Myths. Odense: Odense University Press. 
Clunies Ross, Margaret 2009. “Fornaldarsögur as Fantastic Ethnographies” In A. Ney. Á. Jakobsson \& A. Lassen (eds.), Fornaldarsagaerne: myter og virkelighed. Studier i de oldislandske fornaldarsögur Norðurlanda. København: Museum Tusculanum Press, pp. 317330.

Coser, Lewis A. 1992. "Introduction” In: M. Halbwachs, On Collective Memory, Edited, translated and with an Introduction by Lewis A. Coser. Chicago and London: The University of Chicago Press, pp. 24-27.

Fidjestøl, Bjarni 1993. “Bjarni Kolbeinsson” In P. Pulsiano (ed.), Medieval Scandinavia. An Encyclopedia. New York, London: Garland Publishing. p. 48.

Finlay, Alison 2006. "History and Fantasy in Jómsvíkinga saga” In J. McKinnell, D. Ashurst \& D. Kick (eds.), The fantastic in Old Norse/Icelandic Literature. Sagas and the British Isles. Preprints of the $13^{\text {th }}$ International Saga Conference, Durham and York, $6^{\text {th }}-12^{\text {th }}$ August, 2006. Vol. I, pp. 248-257.

Goody, Jack 1987. The Interface Between the Written and the Oral. Cambridge: Cambridge University Press.

Glauset, Jürg 2007. “The Speaking Bodies of Saga Texts” In J. Quinn, K. Heslop \& T. Wills (eds.), Learning and Understanding in the Old Norse World. Essays in Honour of Margaret Clunies Ross. Turnhout: Brepols, pp. 13-26.

Glauser, Jürg 2009 [2000]. "Sagas of Icelanders (Íslendingasögur) and pattir as the literary rerepsentation of a new social space" In M. Clunies Ross (ed.), Old Icelandic Literature and Society. Cambridge: Cambridge University Press, pp. 203-220.

Gunnell, Terry 2008. “Introduction” In T. Gunnell (ed.), Legends and Landscape. Reykjavík: University of Iceland Press, pp. 13-24.

Harris, Joseph 2010. “Old Norse Memorial Discourse between Orality and Literacy” In S. Ranković, L. Melve, and E. Mundal (eds.) Along the Oral-Written Continuum: Types fo Texts, Relations, and Their Implications. Turnhout: Brepols, pp. 120-33

Hastrup, Kirsten 1998. A Place Apart. An Anthropological Study of the Icelandic World. Oxford: Clarendon.

Hermann, Pernille 2013. "Saga Literature, Cultural Memory, and Storage", Scandinavian Studies vol. 85, 3:2013, pp. 332-354.

Hermann, Pernille, Mitchell, Stephen A. \& Arnórsdóttir, Agnes S. (eds.) 2014. Minni and Muninn. Memory in Medieval Nordic Culture. Turnhout: Brepols.

Hermann, Pernille 2014. "Key Aspects of Memory and Remembering in Old Norse-Icelandic Literature" In P. Hermann, S.A. Mitchell \& A.S. Arnórsdóttir (eds.), Minni and Muninn. Memory in Medieval Nordic Culture. Turnhout: Brepols, pp. 13-39.

Hollander, Lee M. 2008 [1955] (transl.). The saga of the Jómsvíkings. Austin: University of Texas Press.

Jakobsson, Sverrir 2005. Við og veröldin. Heimsmynd Íslendinga 1100 - 1400. Reykjavík: Háskólaútgáfan. 
Lethbridge, Emily 2012."Bjarni byskup Kolbeinsson” In Diana Whaley (ed.), Poetry from the Kings’ Sagas 1: part 2. Turnhout: Brepols, pp. $954-997$.

Lihammer, Anna 2007. Bortom Riksbildningen. Människor, landskap och makt i sydöstra Skandinavien. Lund Studies in Archaeology 7. Lund.

Marold, Edith 1996. "Zum Geschichtsbild der Fornaldarsaga” In R. Simek (ed.), Arbeiten zur Skandinavistik XII: Arbeitstagung der deutschsprachigen Skandinavistik 16.-23. September 1995 in Greifswald. Wien: Fassbaender, pp. 194-209.

Megaard, John 2000. "Studier i Jómsvíkinga sagas stemma”. Arkiv för nordisk filologi 115, pp. 125-182.

Morawiec, Jakub 2009. Vikings among the Slavs.Jomsborg and the Jomsvikings in Old Norse Tradition. Studia Medievalia Septentrionalia Bd. 17. Wien: Fassbaender.

Nora, Pierre 1989. "Between Memory and History: Les Lieux de Mémoire.” Representations 26 (Spring 1989), pp. 7-24.

Petrulevich, Alexandra 2009. “On the etymology of at Jómi, Jumne and Jómsborg” Namn och Bygd årg. 97, 2009, pp. 65-97.

Petrulevich, Alexandra 2013. “"'Burstaborg och Steinborg i Knýtlinga saga - bevis på språkkontakt i kustområdet?” In T. K. Jakobsen (red.), Navne i kystkulturen : forelasninger fra det 41. NORNA-symposium i Tórshavn 2.-4. juni 2011, pp. 168-194.

Petrulevich, Alexandra 2016. Ortnamnspassning som process. En undersökning av vendiska ortnamn och ortnamnsvarianter i Knýtlinga saga. Uppsala: Uppsala universitet.

Spurkland, Terje 2012. “Lygisogur, skrøksøgur and stjúpmœðrasogur” In: Á. Jakobsson, A. Lassen \& A. Ney (eds.), The Legendary Sagas. Origins and Development. Reykjavík:

University of Iceland Press, pp. 173-184.

Stanisławski, Błażej. 2003. "The Mammen style from West Pomerania (Wolin and Kamień Pomorski)". Viking Heritage Magazine 3, pp. 3-5.

Whaley, Diana 2009. “A Useful Past: Historical Writing in Medieval Iceland” In M. Clunies Ross (ed.), Old Icelandic Literature and Society. Cambridge: Cambridge University Press, pp. 161-202.

Townend, Matthew 2012. “Tøgdrápa” In Diana Whaley (ed.), Poetry from the Kings' Sagas 1: part 2. Turnhout: Brepols, pp. 851-863.

Yates, Francis 1966. The Art of Memory. Chicago: University of Chicago Press. 